\title{
Micro credit and its Importance/methodologies
}

\author{
${ }^{1}$ Prof. Deepak R, ${ }^{2}$ Swati K. Shukla, ${ }^{3}$ Abhishek Kumar
}

\begin{abstract}
Finding a single source of reference for having access to money in the $21^{\text {st }}$ century is as easy as looking at the magician magically turning cards into money. Most of them would not agree with the above statement stating the difficulties faced by the rural India. Has micro finance played the role it was supposed to? This paper tries to validate the facts by providing a multi-dimensional approach to the progress of micro finance particularly in India and abroad. "If we are looking for one single action which will enable the poor to overcome their poverty, I would focus on credit" by Dr. Muhammad Yunus, Grameen Bank's founder truly created unparalleled curiosity in providing micro credit facilities to the poor in the form of group lending across the globe.

India is a young country with immense potential. India is among the few emerging countries in the world to have a capability to be one of the powerful nations in the world. The major portion of the age pyramid as shown in the figure 1 clearly pinpoints the fact that Indian population will be represented by young and energetic population for many years to come. This youngistan needs to be nurtured, educated and should be kept away from the vagaries of life mainly from poverty and hunger.
\end{abstract}

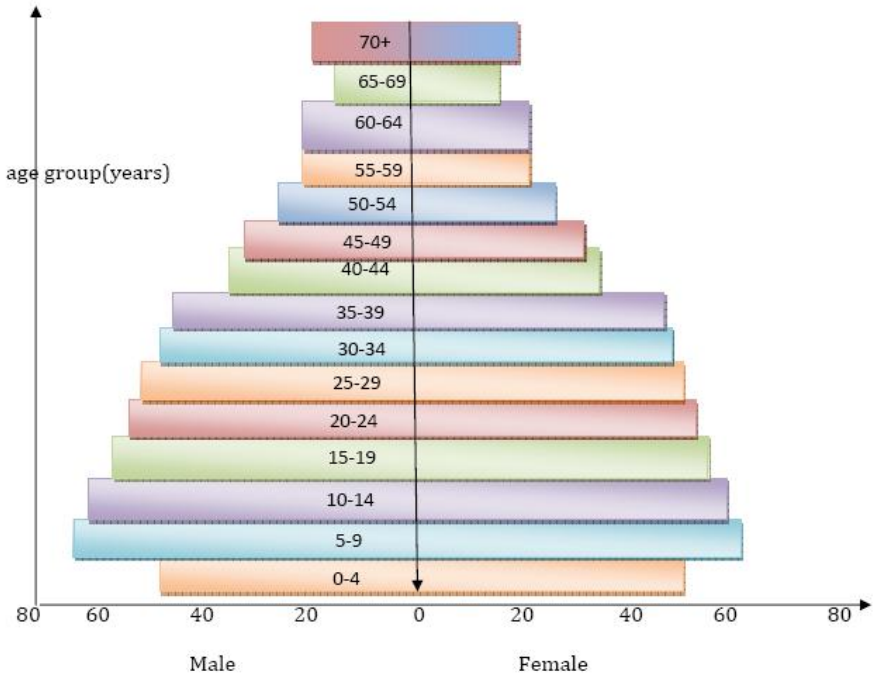

Figure 1 Age wise classification of male and female population in India. (In ‘000’000)

Source: Census 2001

Poverty is the worst nightmare for any developing country as it not only hampers the pace of the growth of the economy but it also prevents the growth in the standard of living of the people of the same. Any developing country's top priority is to alleviate the poverty in the respective country for which governmental initiatives especially programmes like providing micro credit facilities through different channels has played a major and pivotal role.

India has been in times gone by being a pastoral realm with the bulkiness of its population residing in far flung areas. But the rate at which population has increased in past few decades as evident from the table 1 concerns policy makers.

\begin{tabular}{|c|c|}
\hline & Total Population of India \\
\hline & (Number in Lakhs) \\
Year & Total Population \\
$\mathbf{1 9 0 1}$ & 2251 \\
$\mathbf{1 9 1 1}$ & 2451 \\
$\mathbf{1 9 2 1}$ & 2436 \\
$\mathbf{1 9 3 1}$ & 2708 \\
$\mathbf{1 9 4 1}$ & 3090 \\
$\mathbf{1 9 5 1}$ & 3706 \\
$\mathbf{1 9 6 1}$ & 4355 \\
\hline
\end{tabular}




\begin{tabular}{l|c}
\hline $\mathbf{1 9 7 1}$ & 5482 \\
$\mathbf{1 9 8 1}$ & 6726 \\
$\mathbf{1 9 9 1}$ & 8464 \\
\hline \hline $\mathbf{2 0 0 1}$ & 10287 \\
\hline
\end{tabular}

Table 1 Population of India form 1901 to 2001 Source: Census of India

If variable TIME is constructed artificially and is called a time trend or time dummy. Then, Time $_{t}=t$, where Time $=(1,2,3, \ldots \ldots . \mathrm{T}-1, \mathrm{~T}) . \beta_{0}$ is the regression intercept; $\beta_{1}$ is the regression slope;

\section{The simple linear function of time is shown by the following equation}

$$
\begin{aligned}
T_{t} & =\beta_{0}+\beta_{1} \text { TIME }_{t}+\varepsilon_{t} \\
\text { Where } & \varepsilon_{\mathrm{t}} \approx \mathbf{W N}\left(0, \sigma^{2}\right)
\end{aligned}
$$

On regressing the statistics of population of India with the linear trend taking the time dummy variable we realize the tremendous surge in the growth rate.

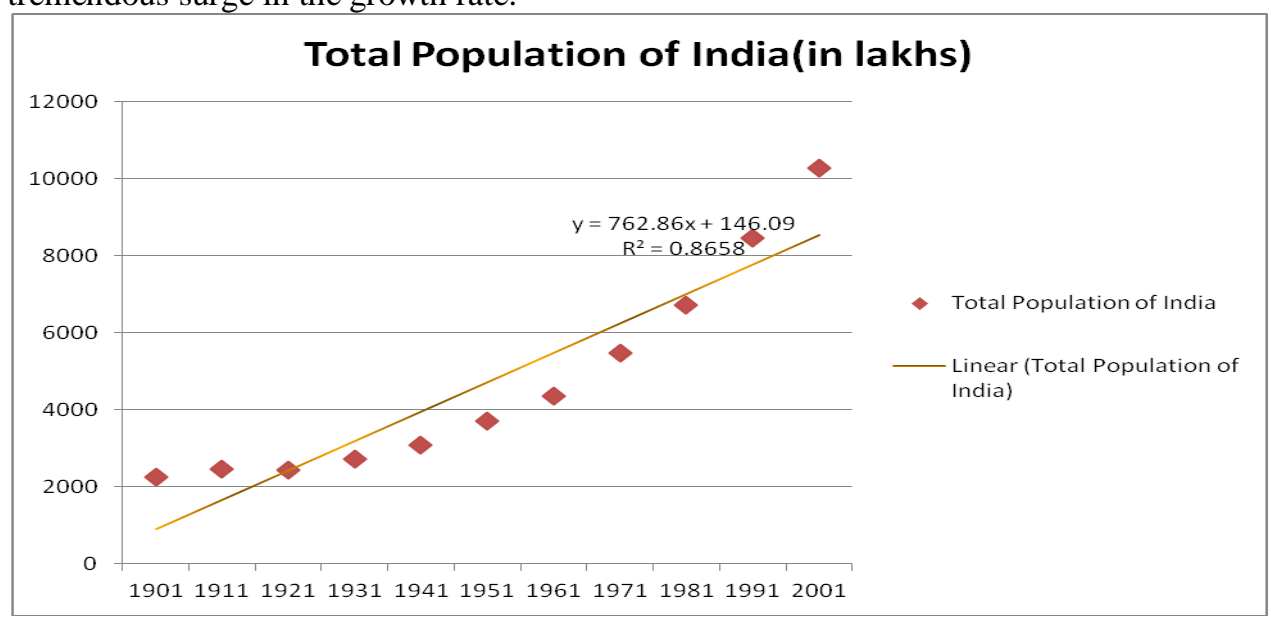

Figure 2 Linear trend superimposed on the population of India Source: Authors

In Figure 2, we show the results of fitting a linear trend model by regressing statistics of Population of India on constant and linear time trend. The trend appears significant as judged by $R^{2}$ of the regression equation which is 0.8658 but linear trend fails to capture the trend.

The trend line of the Population appears to be nonlinear i.e., it increases at an increasing or decreasing rate. Therefore the quadratic/polynomial models can be able to potentially capture nonlinearities as opposed to linear functions of time. As seen in figure 3, Polynomial trend line makes no mistake in capturing the trend of the population growth. The polynomial trend line fits perfectly and is highly significant with $R^{2}$ of the regression equation to be 0.9995 . Polynomial trend line truly captures the non-linearity and by using the estimated equation i.e., $y=5.6546 \mathrm{x}^{3}+4.5023 \mathrm{x}^{2}-2.5159 \mathrm{x}+2292$, we extrapolated the population by another few decades to arrive at around 1.6 billion by 2021 .

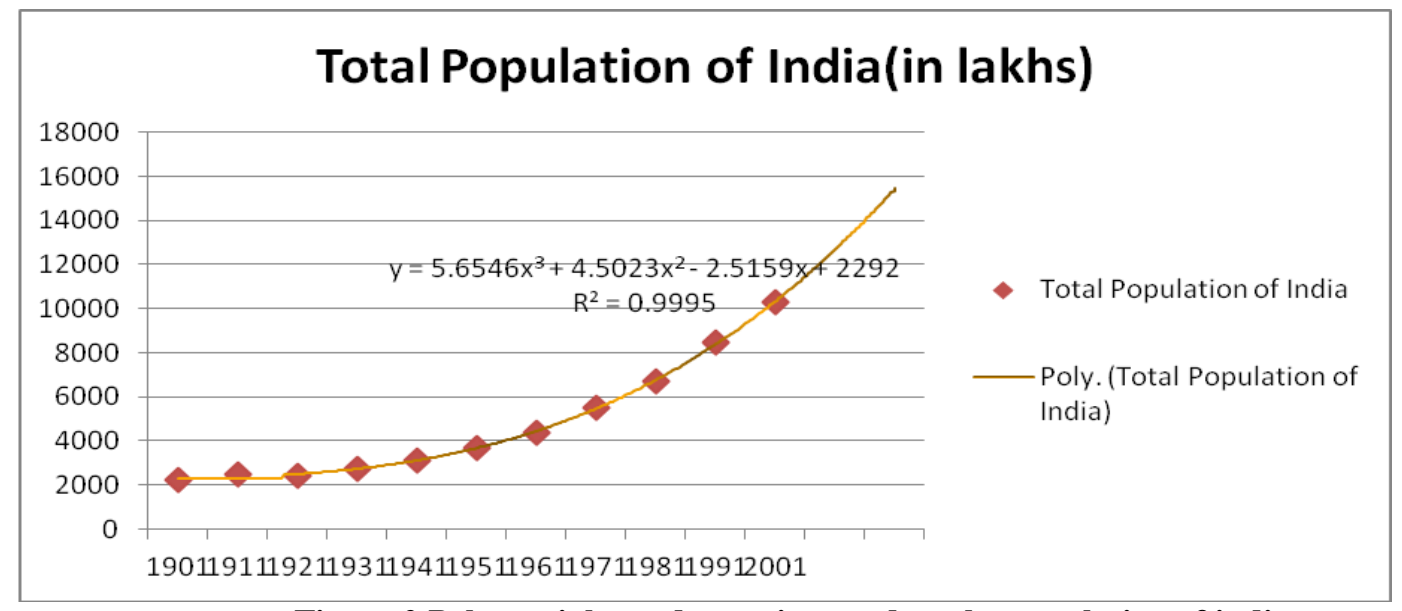

Figure 2 Polynomial trend superimposed on the population of india Source: Authors 
The opportunity available in the semi urban, urban and metropolitan cities has been a reason for the migration of population from rural india. The table 2 clearly shows the urban-rural divide from the census data from 1951 to 2001. As population increases availability of income, education, food, etc... becomes a predicament for the nation.

\begin{tabular}{|c|c|c|c|c|c|c|}
\hline & \multicolumn{7}{|c|}{ Population from 1951 to 2001 } \\
\hline & 1951 & 1961 & 1971 & 1981 & 1991 & 2001 \\
\hline \multirow{2}{*}{ Rural } & $62,443,709$ & $78,936,603$ & 109113977 & $159,462,547$ & $217,611,012$ & $286,119,689$ \\
\hline \multirow{2}{*}{ Urban } & $298,644,381$ & $360,298,168$ & $439,045,675$ & $523,866,550$ & $628,691,676$ & $742,490,639$ \\
\hline
\end{tabular}

Table 2 Population of India from 1951-2001, Rural-Urban divide

Source: Census of India

If only rural areas are focused upon, agriculture still exists as the main occupation. The rural poor, even the poorest by any definition, also have some incomes. But, the flow of income tends to be not constant since agriculture is dependent mainly on rainfall in India. No one can predict the vagaries of nature and hence incomes of the rural poor remain unpredictable. Rural poor very rarely have savings and even if they save, the money is meager. The savings can vary from minimum of Rs 10 onwards. With less than a dollar in a month, they also need small loans, for varying periods, to tide over emergencies which are frequent, and also to manage their livelihood needs. Due to inability of villagers in keeping safe the tiny surpluses, there credit needs heightens. In order to help the poor with the small credits, institutions like NABARD were formed for granting small micro credits to groups of rural poor. From 2001 onwards, in order to overcome the difficulties faced by the banks in lending small loans to the rural poor due to higher transactions cost and due to oppurtunities seen from the emergence of new social class in the urban areas I,e., middle class due to the rural-urban divide as seen in figure 3, various cross-cultural channels were invented and few were learnt from the experiences of other countries.

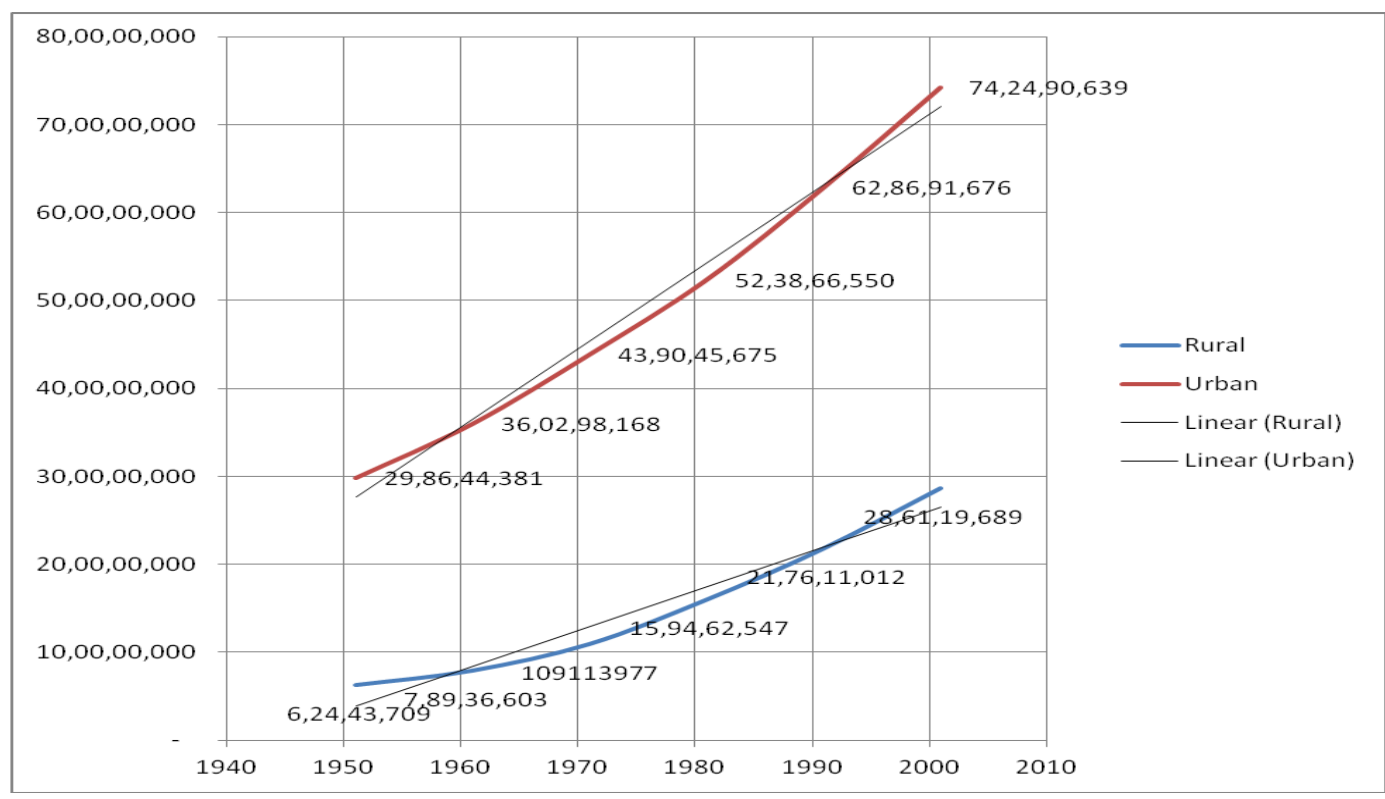

Figure 3 Population from 1951-2001, Urban-Rural Divide

Source: Census of India

Micro credit was indeed the answer to alleviating poverty in the country.

According to Wikipedia, "Microcredit is the extension of very small loans called microloans to those people who are below poverty line and these loans are designed to spur entrepreneurship among them". Often it is mistaken as Microfinance, but actually it is a part of micro credit.

Concept of micro credit has become popular throughout the world and from various journals on microfinance we clearly see various formulations being followed by various governments of the countries across the world. Few of them can be categorized as follows:

a) Traditional micro credit.

b) Informal group micro credit. 
c) Activity based micro credit.

d) Rural credit.

e) Grameen credit.

f) Consumer micro credit.

g) Cooperative micro credit.

h) Bank- NGO micro credit.

i) Other non NGO and non collateralized micro credit.

The various micro credit lending models throughout the world have been successful because of their customization to the respective countries. Few of these models can be briefed as follows:

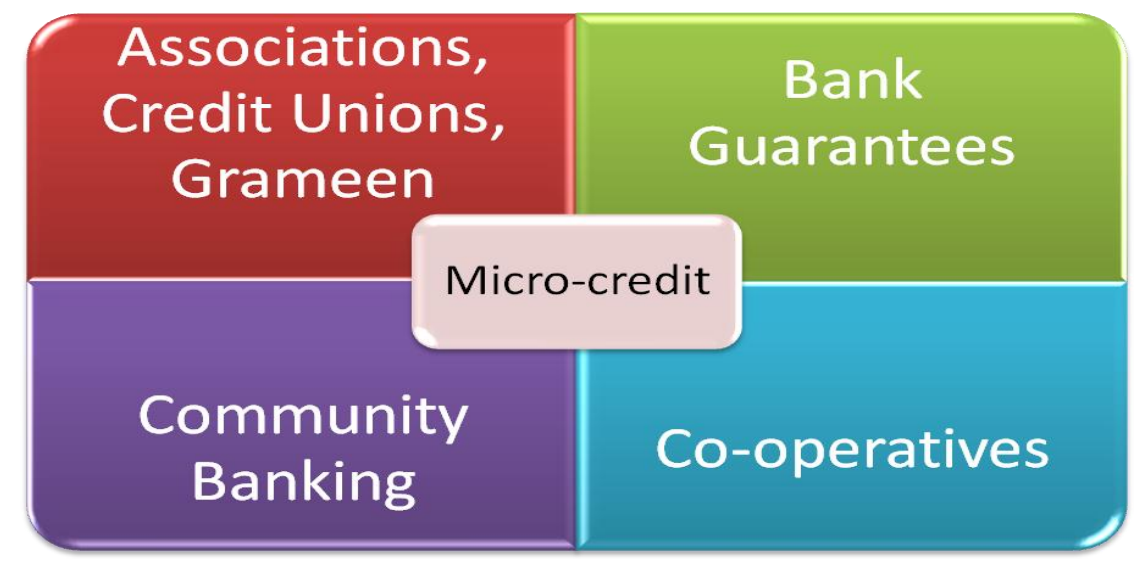

Figure 4 Multiple lending models in different countries

1) Associations - The formation take place in the form of small associations or group of youths or women with a view to initiate savings and channelized it for the support of microenterprises and other work based issues through the way of various micro finance activities.

2) Bank guarantees - on the basis of a donor or donation or any government agency or even the groups' savings is used as a guarantee for obtaining a loan from a commercial bank. These guaranteed funds can be used for various purposes, which can be taken directly by any individual or any formation of self group. For the aid of this model several international institutions and UN organizations have been creating international guarantee fund which can be availed by banks or any NGO.

3) Community banking - This model treats the community as a whole group and other semi-formal institutions for dispense of microfinance. This model works with the extensive help of the NGOs and other organizations present in the area for the effective dispense of the money as well as for the training of community members in various economic activities of the community.

4) Cooperatives - An autonomous association of like-minded people unite voluntarily to meet their common economic, social, and cultural needs and aspirations through a jointly-owned and democratically-controlled enterprise. Some cooperatives include member-financing and savings activities in their mandate.

5) Credit unions -it is a self help institutions owned and governed by own members where they can elect their own directors and representatives where they save the money to make loans to each other at reasonable rates of interest. It is built for nonprofit financial cooperative and its membership is open to all the people of the group.

6) Grameen: The bank helps in educating people in villages in various aspects. The bank unit with a field worker and number of workers visit the villages to acquaint themselves with the local milieu in which they will be operating and they identify prospective clientele, as well as explain the purpose, functions, and mode of operation of the bank to the local population. In the Incubation period, the repayment status is studies and then if found good, a small loan amount is provided to inculcate saving habits and unity. Here the peer pressure plays an important role to keep the individual record clear.

7) Individual: Usually this model is used in a large credit programme or in social-economic services wherein skill development, education and various other outreach services are provided.

8) Intermediaries: The intermediary role between the banks and the self-help groups is played by predominantly NGOs, microcredit programmes, commercial banks or any international donors who plays an important role of generating credit awareness and education as well as savings for the borrowers.

Poverty is not a menace, but an opportunity to improve. Micro-credit channels in various countries have made substantial efforts in alleviating poverty. Rural Poor need a lending hand which not only supplies them with adequate tools and mechanism for uplifting their standard of living but shows them various ways to sustain it; which can be possessed through community learning. The micro credit facilities satisfy the 
main barrier which is the lack of sufficient credit to purchase inventory or equipment needed to establish sustainable small enterprises and through the peer pressure among the group members the credit is repaid back.

The presumptions that "lending to the poor are bad credit risks without collateral" and "less profitable than larger loans" are slowly changing grounds.

Success comes from failures and by understanding the diversity of the cultures which in turn makes the situation much more complex. But adopting a model to our country presents biggest challenges in terms of; how to replicate and adapt successful experiences with microcredit to vastly different cultural and social circumstances. The different models adopted across continents are briefed as follows:

\section{Europe:}

Micro credits have matured in terms of their reach and uniqueness in European countries. They are distinctive by allowing people at risk of social exclusion to engage in an economic activity and by playing a key role in tackling the issues of business development, job creation and social cohesion through expanded provision of access to finance.

Savings banks specially European Savings Banks Group (ESBG) play a key role in increasing the level of access of financial services for all European citizens.

The various models which have been implemented in Europe are as follows:
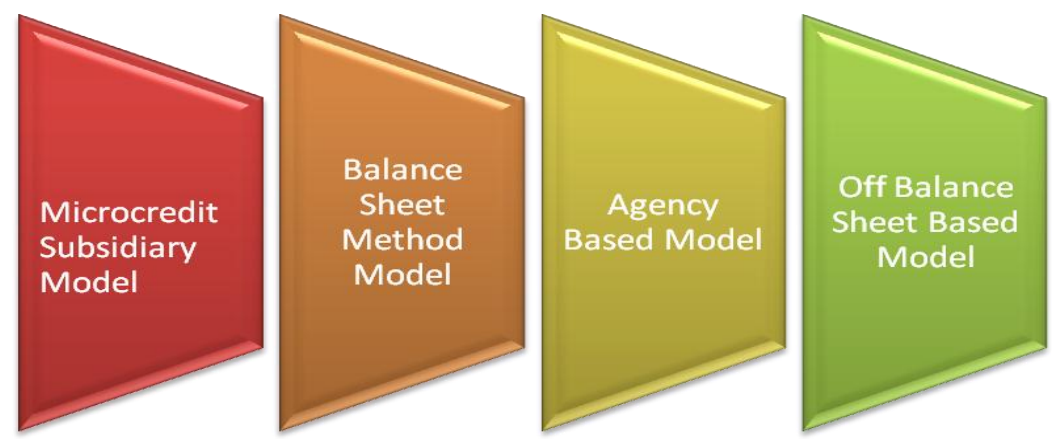

Figure 5 Micro credit Models implemented in European countries.

1. Microcredit subsidiary model: In this model, a bank subsidiary in entirety is dedicated to provide microcredit. Social micro credits are managed in collaboration with support organizations that will monitor the client performance and financial micro credits are managed entirely by bank.

2. Balance sheet method model: The model is characterized by a direct relationship between the savings bank and the beneficiaries of micro credit. They help in providing credit products for businesses with flexible maturities and with options for different collaterals, appropriate interest rates and various other credit schemes. Uniqueness exists in terms of extended grace periods for the credits and provides loans to unemployed people too.

3. Agency based model: The model is basically dependent on agency relationship with national and international financial institutions which in turn work through local financial institutions, such as savings banks, which are 100\% risk exempted. The credit policy is defined by fund providers and applied by the lending institution.

4. Off balance sheet based model: In this model the profits and losses are not consolidated in the bank's financial statements. Savings banks provide non-recoverable funds to their foundations or solidarity institutions that provide microcredit and social services.

\section{Cameroon}

Here the consumer credit is combined with the formal and informal finance and also has some features of credit cards as well as travelers check. SHGs deposit their funds in bank accounts. Based on this collateral bank issues a check like instrument called flash cash to members of the group who can cash these checks at any store that participates in the program with the bank. ${ }^{1}$

\footnotetext{
${ }^{1}$ http://www.gdrc.org/icm/inspire/flash-cash.html
} 
Micro credit and its Importance/methodologies

\section{Malaysia:}

The model followed is similar to Grameen Bank in Bangladesh where they provide interest free loan to borrowers to undertake income generating projects. Loans once repaid (usually weekly), bigger loans can be offered to the group. Along with it these groups will undergo a one week compulsory training of one hour per day to understand their rights and obligations in order to ensure good repayment. If there is lack of institutions in certain regions, then government post offices act as financial intermediaries.

\section{Mogadishu:}

Mogadishu is unique in terms of its focus on family. The model helps in providing credit for both women of the family and for the children's education (enrollment fee for joining village primary school). Along with credit they provide three months of numeracy, literacy and business development training and a guarantee of an extended loan of certain amount in future. This method can definitely be a keystone for alleviating poverty and for creating awareness regarding education in rural areas.

\section{China:}

Wokai is a microfinance organization that helps impoverished residents of rural regions in China to improve their own living conditions. Small loans are given to rural farmers and others to empower them and to help them fund their own economic ventures, the organization then collects and maintains information regarding loan recipients and posts this information on its website. Donors can browse recipients and choose which person they'd like to loan money to. And once a loan is repaid then the donor can choose any other recipient from the basic loan. Thus in one way one donation can help multiple recipients.

\section{Bangladesh:}

The Norwegian Nobel Committee decided on year 2006 to award prestigious Nobel Peace Prize to both Muhammad Yunus and Grameen Bank for their efforts to create economic and social development. Grameen Bank was started against the advice of commercial banks, in 1983. Grameen Bank, meaning 'village bank' was founded on principles of trust and solidarity. Grameen Bank boosts itself to have around 2539 branches, and around 6.21 million active borrowers.

\begin{tabular}{|l|c|c|c|r|r|r|r|}
\hline \multicolumn{7}{|c|}{ Outreach indicators: } \\
\hline & 2002 & \multicolumn{1}{|c|}{2003} & 2004 & \multicolumn{1}{c|}{2005} & \multicolumn{1}{c|}{2006} & \multicolumn{1}{c|}{2007} & \multicolumn{1}{c|}{2008} \\
\hline Number of branches & 1,178 & 1,195 & 1,358 & 1,735 & 2,319 & 2,481 & 2,539 \\
\hline $\begin{array}{l}\text { Number of members (In } \\
\text { millions) }\end{array}$ & 2.48 & 3.12 & 4.06 & 5.58 & 6.91 & 7.41 & 7.67 \\
\hline $\begin{array}{l}\text { Number of active } \\
\text { borrowers (In millions) }\end{array}$ & 2.08 & 2.87 & 3.7 & 5.05 & 5.96 & 6.16 & 6.21 \\
\hline $\begin{array}{l}\text { Number of active } \\
\text { borrowers per branch } \\
\text { (year-end) }\end{array}$ & 1,766 & 2,402 & 2,722 & 2,912 & 2,571 & 2,482 & 2,448 \\
\hline Number of loan officers & 7,448 & 7,495 & 7,925 & 9,166 & 12,048 & 14,561 & 14,000 \\
\hline $\begin{array}{l}\text { Percent of women } \\
\text { members }\end{array}$ & $95.20 \%$ & $95.44 \%$ & $95.66 \%$ & $96.27 \%$ & $96.70 \%$ & $96.85 \%$ & $96.88 \%$ \\
\hline $\begin{array}{l}\text { Average loan balance per } \\
\text { borrower (Taka) }\end{array}$ & 6,134 & 5,622 & 5,444 & 5,563 & 5,578 & 5,901 & 7,147 \\
\hline $\begin{array}{l}\text { Average loan balance per } \\
\text { borrower (USD) }\end{array}$ & 106 & 96 & 90 & 85 & 80 & 86 & 104 \\
\hline
\end{tabular}

Table 3 Outreach indicators of Grameen Bank from 2002 to 2008

Source: www.grameen-bank.org

\begin{tabular}{|l|c|c|c|c|c|c|c|}
\hline \multicolumn{7}{|c|}{ Sustainability/Profitability ratios: Grameen Bank } \\
\hline & 2002 & 2003 & 2004 & 2005 & 2006 & 2007 & 2008 \\
\hline Return on equity (ROE) & $2.93 \%$ & $10.63 \%$ & $8.98 \%$ & $21.22 \%$ & $25.83 \%$ & $1.79 \%$ & $21.21 \%$ \\
\hline $\begin{array}{l}\text { Operating self sufficiency } \\
\text { (OSS) }\end{array}$ & $102.00 \%$ & $111.10 \%$ & $109.88 \%$ & $115.65 \%$ & $117.41 \%$ & $101.02 \%$ & $112.20 \%$ \\
\hline $\begin{array}{l}\text { Financial self sufficiency } \\
\text { (FSS) }\end{array}$ & $99.60 \%$ & $107.88 \%$ & $105.70 \%$ & $110.40 \%$ & $112.28 \%$ & $94.84 \%$ & $106.07 \%$ \\
\hline
\end{tabular}

Table 3 Sustainability/Profitability ratios of Grameen Bank from 2002 to 2008 
Source: $\underline{\text { www.grameen-bank.org }}$

As shown in the table 3, Grameen Bank had 2,539 branches in 2008. The proportion of women members was a whopping $96.88 \%$, which has been the key for its success in Bangladesh. From the table 4, we can analyze the effectiveness of the Grameen bank model in terms of polynomial growth in ROE. According to the monthly report on November $10^{\text {th }}, 2009$, the cumulative assets disbursed since inception is 8532.48 US\$ and the rate of recovery stands at $96.79 \%$. So, overall Repayment rates, the success of individual micro-enterprises established, and the ability of microcredit programs to become financially self-sustaining were the important indicators of success.

\section{Conclusion:}

From the research it is clearly evident that any institution can survive, only if it involves favorable cultural, rural, agricultural and macroeconomic policies. India can reach its goal of becoming superpower only if adequate investments are done in both physical and social rural infrastructure and innovating low-cost mobile distribution systems with flexible credit opportunities which would help in mobilizing domestic savings. For efficient performance of the microcredit models, close monitoring of loan performance should be a criteria which will definitely facilitate effective planning in the future. So, "Unity in Diversity" should be main motto of success for microcredit in India.

\section{References:}

[1] The European voice of savings and retail banking (ESBG), September 2007

[2] Micro Credit and Rural Poverty: An Analysis of Empirical Evidence, Pallavi Chavan, R Ramkumar

[3] Tina Wallace, Review of African Political Economy No.71:35-55, New Development Agendas: Changes in UK NGO Policies \& Procedures;

[4] Kavaljit Singh and Daphne Wysham, “Micro-credit: Band-aid or wound?" The Hindustan Times, January $29,1997$.

[5]

\section{Webliography:}

[6] http://banktani.tripod.com/microfinance.htm

[7] http://www.grameeninfo.org/index.php?option=com_content\&task=view\&id=218\&Itemid=172\&limit=1\&limitstart=4

[8] http://profiles-non-profits.suite101.com/article.cfm/wokai_a_chinabased_microfinance_ngo\#ixzz0W0OYJkWB

[9] http://www.grameen-info.org/index.php?option=com_content\&task=view\&id=22\&Itemid=109

[10] http://www.gdrc.org/icm/model/1 -credit-model.html

[11] http://www.gdrc.org/icm/data/d-snapshot.html 